\title{
ALPHONSE MERRHEIM AND THE STRIKE OF HENNEBONT: THE STRUGGLE FOR THE EIGHT-HOUR DAY IN FRANCE
}

On May 1, 1906, the Confédération Générale du Travail (CGT), the national organization of French revolutionary syndicalism, demanded that the French government reduce the legal work day for industrial workers to eight hours. The CGT would back this request with force, and it called upon all workers to strike by May 2. The response was overwhelming; work-stoppage was widespread, and it appeared that government and industry would have to yield. By May 2, over 200,000 workers had walked off the job. The number of establishments affected was impressive. 295 strikes which called specifically for a work-day reduction involved 12,585 firms, a high figure compared to previous years. (Strikes for a ten-, nine-, or eight-hour work day were a part of the CGT's eight hour day movement.) For instance, only $14 \%$ of the strikes in 1904 and $16 \%$ in 1905 aimed primarily at a work-day reduction compared to $64 \%$ in $1906 .^{1}$ Also, in 1905 , there were only a total of 830 strikes affecting 177,666 workers and 5,302 establishments, while in 1904, 271,097 workers participated in 1,026 strikes involving 17,250 establishments. ${ }^{2}$ By comparison, the total number of firms struck in 1906 was 19,637 and involved 438,466 workers in 1,309 strikes. ${ }^{3}$ The Ministry of Labor conceded that the increased number had resulted from the CGT's eight-hour day movement.4

This turnout and some gains convinced CGT leaders that their campaign had been successful, and the tenacity of some workers added to the impression. Twenty-one strikes in 1906 had lasted over a hundred days. ${ }^{5}$ The government, in turn, granted the strikers a mandatory weekly rest period (July 13, 1906). It announced, too, its

1 Maurice Dommanget, Histoire du Premier Mai (Paris, 1953), pp. 223-224.

2 Statistiques des Grèves, 1904, p. v; ibid., 1905, p. v, and Bulletin de l'Office du Travail, 13e année, no 5, Mai, 1906, p. 454.

${ }^{3}$ Statistiques des Grèves, 1906, pp. v-vi and 777.

4 Statistiques des Grèves, 1906, pp. v-vi.

5 Statistiques des Grèves, 1906, pp. x-xi. 
intention of reducing to a ten-hour maximum the legal work day. (It did not grant the eight-hour work day which French workers would finally obtain in 1919.) These developments prompted the anarchist Jean Grave to write, "It [the strike movement] signalled the revival of the proletariat." Paul Marius André, a Guesdist, commented that "the number of strikers had considerably increased in proportion to preceding years, and never, perhaps, had the glorious May 1 [movement] mobilized so many working class forces as it had this year." The syndicalist newspaper and organ of the CGT, La Voix du Peuple, which was more restrained in its estimation, wrote "that the movement was real and this was the first time in France that there had occurred an upheaval of such force and breadth." The CGT's Congress of Amiens (October 8-16, 1906) agreed. "The demonstration was imposing", it reported. ${ }^{1}$ Maurice Dommanget, historian of the May 1 movement, regarded these estimations as valid. The high incidence of strikes and the workers' vigorous support, he wrote, was more important than any of the concessions which had been obtained. And "from the moral point of view, it was incontestable that the consciousness, hope and cohesion of the working class had been considerably reinforced."2 Moreover, in 1906, syndicalists believed that the strikes had spread revolutionary ideas, which were more important than concrete gains, and thus brought closer the social revolution.

In spite of this initial enthusiasm, however, French syndicalism began to lose its revolutionary élan after 1906. A strong anti-labor government led by Georges Clemenceau, the steadily expanding and relatively stable economy, and dissensions within the CGT contributed to this decline. The material failure of the 1906 strikes and the lessons derived from them in reflective moments by some syndicalists also took their toll. The government successfully resisted the strikers' primary demand for a reduced work day. Only 10,177 workers out of 202,507 obtained any reduction of the work day. ${ }^{3}$ Furthermore, shortly after 1906 , some syndicalists found their over-all strength wanting when compared to that of the government and employers. Consequently, they despaired of obtaining significant reforms quickly. In the forefront of those who questioned the capacity of revolutionary syndicalism was Alphonse Merrheim, secretary of the Federation of Metal Workers, and leader of the metal workers strike at Hennebont, one of the many which had made up the May 1, 1906 movement. Merrheim, because of his participation in this and earlier strikes, discovered that employers were

${ }^{1}$ Quoted by Dommanget, op. cit., p. 226.

2 Dommanget, op. cit., pp. 223-225.

${ }^{3}$ Statistiques des Grèves, 1906, pp. 781-783. 
exceedingly powerful, well-organized, and had close ties with the government. He published his findings, which convinced him and many co-syndicalists that they would have to unionize more efficiently before another major confrontation with either the government or employers. The thorough participation of Merrheim in trade unionism, however, blunted his revolutionary capacity. Since many in the CGT followed his advice and leadership, his attitude also affected them. In this context, no strike better illustrates the failure and consequences of the 1906 May Day movement in France than the one at Hennebont.

\section{I}

Long before the CGT struck on May 1, 1906, European and American working class organizations had established the practice of holding demonstrations or work stoppages annually on May 1 to force governments or employers to grant a legal eight-hour work day. ${ }^{1}$ An incident in America established the definitive connection between the eighthour day demonstrations and May 1. The American Federation of Labor, meeting in Chicago in 1884, planned a rally for the shorter work day for May 1, 1886. The event turned into a tragedy, which gave special meaning to the date. Chicago workers struck on May 1 and were treated roughly by the police. On May 3 some 7 to 8,000 strikers faced police, Pinkerton guards, and strike breakers of the McCormick International Harvester Company at Haymarket Square. Someone fired a shot and a general melee followed. Police killed six workers and wounded 50. The government arrested strike leaders, tried and convicted them, and on November 11, 1887 executed four. Three of the arrested labor leaders were exonerated in 1893. The international working class community was shocked by the killings and to honor the American martyrs chose May 1 as the date for its own eight-hour day demonstrations. Thus an AFL congress in Saint Louis in 1888 voted to start an international eight-hour day movement on May 1, 1890. And the Second International, at its founding Congress of Paris of July, 1889, adopted May 1 as the date for an international demonstration for an eight-hour work day. At its Congress of Brussels (16-22 August 1891) the International conferred upon the date May 1 its annual character. ${ }^{2}$

French socialists and syndicalists also had been developing a May 1

1 For the best discussion of the eight-hour day movement see Maurice Dommanget, op. cit.; also useful is Robert Brécy, La Grève Générale en France (Paris, 1969).

2 Dommanget, op. cit., p. 155. 
tradition before 1906. An important characteristic of French socialist and syndicalist unions was their division. Socialists were represented by competing parties and syndicalists, also disunited, broke with socialism by 1894 and eschewed all political activity. Thus the French May Day movement was based on varied sources. For example, the Parti Ouvrier Français (POF), headed by Jules Guesde, had committed itself by 1880 to an eight-hour work day for adults and six for children. Efforts to obtain the reform, the party believed, should be legal. The Fédération nationale des Syndicats, a workers' federation with a Guesdist majority, met in Bordeaux in October-November, 1888 and decided to strike in February, 1889 for demands which included the eight-hour work day. The Congress of Bordeaux was the first French workers congress to adopt the general strike as a means of obtaining a specific demand. The congress stated "that alone, the general strike, that is to say a complete work-stoppage or revolution, can bring the workers their emancipation." 1

Important individuals also contributed ideas to the May 1 tradition. Aristide Briand played a leading role at workers' congresses and unions by insisting on the revolutionary nature of the general strike and the May 1 movement. He joined with the important syndicalist leader, Fernand Pelloutier, in directing syndicalists away from the POF. By the early 1890's the party had become preoccupied with winning local elections and believed that the working class was incapable of conducting a general strike. Pelloutier, secretary of the Federation of the Bourses du Travail, a syndicalist federation which united with the CGT in 1902, joined Briand because he believed syndicalists should reject all political activity in favor of more revolutionary "economic direct action". Pelloutier also favored the general strike and the May Day movement, although not always linking both. Briand and Pelloutier's ideas bore fruit in 1894 when a general workers' congress at Nantes accepted the principle of the general strike. The Guesdists attending walked out and the French syndicalist movement remained independent of political parties until after World War I.

French socialists and syndicalists also staged demonstrations on May 1; by 1890 these had become annual events. Work stoppages on May 1, 1890 in Paris and in the provinces were successful, although they did not last much beyond the day. Violence marred May 1, 1891. In Clichy, near Paris, workers and police fired at each other. The government tried and sent to jail two syndicalists for their part in the affair. At Fourmies soldiers fired a Label repeating gun at strikers,

1 Brécy, op. cit., p. 26. 
killing ten. May 1, 1892 was not successful because it came immediately after municipal elections; the government also had troops ready. By 1893 the May 1 demonstrations had become a bore and remained dull until 1904 when the CGT revived them. A hostile middle class press, competition from socialists favoring electoral campaigns, and the seeming arbitrariness of always protesting on the same fixed date contributed to the movement's decline. ${ }^{1}$ Engels concluded simply that May 1 was becoming a habit. ${ }^{2}$

The government and employers joined in repressing workers demonstrations and demands, especially since the rate of strikes increased during the two decades before World War I. ${ }^{3}$ This increase included the May Day strikes. What industrialists especially resented about strikes was the challenge they posed to their authority. Their earliest reaction to them was bitter hostility, stubborn intransigence and inflexibility, and sometimes violence. As time passed, the industrialists developed more novel tools to meet the danger. "Efforts to persuade, threats to dismiss, reliance on police, and use of scabs, in various combinations, represented the most obvious defenses against strikers in this period."4 Employers also yielded frequently on minor claims because these did not threaten their authority and could be rescinded later. For example, they could raise wages easily because prices were rising before 1914 and wages could be cut if conditions changed. In addition, many industrialists combined to meet strikes with a united front and frequently bargained collectively. Strikes against these became increasingly difficult. The government shared the industrialists' aversion to strikes and used police and troops to put them down. These methods accelerated the rate of strike failures after $1906 . .^{5}$

When workers founded the CGT in 1895 at Limoges the May Day movement was on the wane. They were cautious, therefore, about the kind of action they suggested for May 1, 1896. The Congress of Limoges made the eight-hour day part of its minimum program and passed a resolution which stated that the general strike is "the surest and most legal lever for the emancipation of the workers". The resolution recognized, however, that workers were not as yet sufficiently prepared for a general work stoppage. The CGT would wait until it was more

${ }^{1}$ Dommanget, op. cit., pp. 198-200.

2 Dommanget, op. cit., p. 178.

3 Peter Stearns, "Against the Strike Threat: Employer Policy toward Labor Agitation in France, 1900-1914", in: The Journal of Modern History, Vol, 40, No 4, December 1968, pp. 474-475.

4 Ibid., p. 485.

5 Ibid., p. 498. 
powerful before agitating. ${ }^{1}$ Thus the Congress reminded its members of the May 1 tradition, but did not mandate its Executive Committee to make any special preparations for 1896 . Rather it rejected the traditional view of petitioning the government for reforms and invited its members to study means for "more effective" action.

An important step in the CGT's preparations was its creation in December, 1900, of a weekly syndicalist newspaper, La Voix du Peuple. Its editor, Emile Pouget, propagandized for the eight-hour day with considerable ardor and tenacity and played a central role in laying the groundwork for a May 1 movement in the CGT. ${ }^{2}$ In 1902 the CGT was too preoccupied with joining the Bourse du Travail to plan for May 1. By 1904, however, it believed itself strong enough to prepare its own massive demonstrations for an eight-hour work day. The Congress of Bourges (September, 1904), therefore, resolved to call a general strike for May 1, 1906. The May Day movement was on the upswing again, and between 1904 and 1906 it was the CGT's single most important concern.

\section{II}

In 1904 Merrheim was a newly elected secretary of the Federation of Metal Workers. A such he became an active and politically powerful member of the CGT in the years between 1904 and 1923 as well as the most important member of the Federation of Metal Workers during the same period. Merrheim was born on May 7, 1871 in La Madeleine in the Department of the Nord. ${ }^{3}$ His father, Adolphe, was a coppersmith and his mother, Adolphine, a housewife. In 1881, when only 10, Alphonse, as was typical of working class children then, quit the village school to take up employment in a soap factory. When the family moved to the neighboring town of Roubaix, Alphonse, at age 12, took up his father's trade. The young Merrheim was a coppersmith at 16 , but soon became ill as the job proved too strenuous. The only course open to him was to take up another, less rigorous trade, and this he did, becoming a weaver. It was as a young weaver of 18 , in 1889 , that Merrheim entered the POF. Merrheim developed a working class consciousness and he now sought to join with others who believed in working for the betterment and liberation of the proletariat. The POF

1 Dommanget, op. cit., p. 190.

2 Dommanget, op. cit., p. 202.

"The information on Merrheim's life can be found in Nicholas Papayanis, "Alphonse Merrheim and Revolutionary Syndicalism, 1871-1917", a thesis at the University of Wisconsin, Madison, Wisconsin, 1969. The author is currently preparing a biography of Merrheim. 
possessed revolutionary élan, and Merrheim joined it because most industrial workers in the Nord were Guesdists and because he belonged to a Guesdist labor federation, the Federation of Textile Workers. Merrheim, however, left the POF in 1891, soon after he joined, because of a transformation in Guesdism. The POF, which grew rapidly between 1889 and 1893, began to win local elections and offices. By 1892 it openly appealed to urban middle class groups and peasants. Now it seemed guided less by revolutionary or worker needs than by electoral requirements. ${ }^{1}$

Thus opposed to Guesdism, Merrheim soon turned to revolutionary syndicalism, which was currently beginning to organize in the Nord. Revolutionary syndicalists, who believed that the syndicalist movement should prepare workers through social reforms and education for a general strike which would one day overthrow capitalism, convinced Merrheim that their only aim was to liberate the proletariat. He joined them as a copperworker in 1891. By 1893 Merrheim had founded the Coppersmiths' Union of Roubaix-Tourcoing, which was affiliated with the Federation of Copper Workers. Merrheim worked diligently for his union and the federation in the Nord and in 1898 represented the federation in a major unionizing drive it was conducting throughout France. He performed his task well and increasingly came before the attention of federation officials. In 1900 he directed a strike of copper workers in Roubaix-Tourcoing; in 1902 he led major debates at his federation's annual congress.

The Federation of Copper Workers united with the Federation of Metal Workers in 1903. Merrheim, who had become an important member of his own organization, became a secretary of the new federation, the Federation of Metal Workers in June 1904. He moved to its Paris headquarters in July, 1904 and soon became involved in metal workers' strikes in Cluses (1904) and Longwy (1905) which had an important influence on his evolution before the strike of Hennebont. At Cluses, employers who had fired upon and killed striking workers were convicted by a court but were sentenced to only one year in jail and a fine. This incident demonstrated the obvious class bias of French justice to Merrheim. The Longwy strike introduced Merrheim to the existence of international cartels. In 1905 an extensive strike broke out among steel workers and miners in the Department of the Meurthe-etMoselle. During the strike Merrheim discovered that the department's economy was controlled by the "Comptoir de Longwy", an interna-

1 Claude Willard, Les Guesdistes: Le Mouvement Socialiste en France, 18931905 (Paris, 1965), p. 91. 
tional capitalist trust with important government connections. ${ }^{1}$ This revelation spurred Merrheim to investigate precisely how cartels and, later, interlocking directorships worked within the French steel industry. He lacked, however, the indispensable tool for his proposed study, a training in economics. He began reading secondary sources on cartels, but by the time of the Hennebont strike, financial reports still puzzled him. The strike of Hennebont provided the final link between Merrheim's desire for knowledge and the beginning of his mature understanding of the steel industry. For at Hennebont Merrheim met Francis Delaisi, an economist and journalist, who would henceforth assist him in understanding the French economy. And the reports Merrheim would later publish on the French steel industry played a major role in convincing many revolutionary syndicalists to work in a reformist manner.

\section{III}

The CGT's Congress of Bourges officially began the May Day campaign, which would encounter difficulties before and during its course. First, the CGT's eight-hour day committee suggested two tactics to the Congress: (1) The Congress could propose a law to public authorities while workers demonstrated, or (2) workers could exert all possible pressure without petitioning the government. Recommending the second alternative, the committee suggested that the campaign begin on May 1, 1906. The Congress adopted its proposals with Émile Pouget's addition that workers stop working after eight hours on May $1 .^{2}$

The Executive Committee of the CGT undertook a vast propaganda effort to implement this resolution and established a Commission des Huit Heures (Commission for the Eight-Hour Day) chaired by Paul Delesalle. Pouget became its most active member. As for May 1, 1905, the CGT intended it merely to serve as a warm-up for the following year, which it did successfully. Union militants also began organizing and speaking throughout France, and by the end of 1905 union meetings had multiplied. In December, 1905, for instance, ten major

\footnotetext{
1 Alphonse Merrheim, "Dans le Bassin de Longwy: Cynisme capitaliste", in: La Voix du Peuple, no 262, 5e année, October 29 - November 5, 1905, pp. 2-3; and idem, "Le Mouvement Ouvrier dans le Bassin de Longwy", in: Le Mouvement Socialiste, IIe Série, VIIe année, no 168-169, December 1 and 15, 1905, pp. 425-482.

2 Confédération Générale du Travail, XIVe Congrès National Corporatif (Bourges, 1904), p. 205-207 (for the committee's proposal); pp. 204-220 (for the full debate); pp. 219-220 (for the results of the voting).
} 
syndicalists including Merrheim held conferences in eighty cities. A police spy reported agitation in the provinces and he also wrote that the CGT was sending posters to principal industrial centers and to the Bourses $d u$ Travail (Labor Exchanges) to prepare for meetings. ${ }^{1}$ As for Merrheim, he welcomed the organizing drive and urged his men to support it. ${ }^{2}$ He campaigned personally in the Nord, quickly visiting Cateau, Denain, Hautmont, Sous-le-Bois, Anzin, Raismes, Onnaing, Roubaix, and Tourcoing. ${ }^{3} \mathrm{He}$ also arranged regional conferences for metal workers. ${ }^{4}$ His efforts were successful. His own federation supported him because, as one of its manifestoes stated, this campaign became its most important business. The May Day movement would obtain its goals, the manifesto said, and syndicalists would demonstrate their desire for a new society of "Justice, Well-Being, and Liberty". 5 The federation's resolution concerning May 1 was not so enthusiastic, however. It stated that since unions affiliated with the federation are completely autonomous, "It belongs neither to the Congress, nor to the Executive Committee [of the federation] to impose on the unions a specific mode of action. Each union must take inspiration from the resolutions of the [CGT's] Congress of Bourges. "6 The federation then asked all workers and unions to prepare energetically for May 1, 1906. The congress passed this cautious statement because it knew that local metal workers' unions differed from each other in preparedness and revolutionary consciousness.

Merrheim's travels and meetings proved too rigorous for him. ${ }^{7}$ A spy

1 Archives Nationales (hereafter referred to as AN), F 7, 13267, Paris, December $11,1905, \mathrm{M} / 1919$.

2 Alphonse Merrheim, "A Bourges", in: L'Ouvrier Métallurgiste, 14e année (2e Série), no 154 , October 1, 1904, p. 1.

${ }^{3}$ La Voix du Peuple, no 219, 4e année, December 25 - January 1, 1905, p. 2. He also went to the Centre, a trip which prompted a spy to write that Merrheim was a "good orator, prudent in word and deed, but all the more dangerous". See AN, F7, 13267, Paris, December 11, 1905, M/1919.

4 See "Congrès Régional des Ouvriers Métallurgistes de la Région du Nord, tenu à Lille, le 19 Mars 1905, Compte Rendu”, in: L'Ouvrier Métallurgiste, no 160, March 1, 1905, p. 1.

5 The manifesto is in L'Ouvrier Métallurgiste, 15e année (2e Série), no 161, April 1, 1905, p. 1.

- Union Fédérale des Ouvriers Métallurgistes de France, XIIe Congrès National des Ouvriers Métallurgistes (Paris, 1905), pp. 288-295 (report of the Commission on the Eight-Hour Day); pp. 296-297 (the resolution calling for the eight-hour day and for propaganda for May 1, 1906).

7 For instance, on December 25, 1905, a typical day, he conducted a two-hour meeting at Vichy and immediately went to the next town for another. See "Les Meetings des Huit Heures", in: La Voix du Peuple, no 273, 6e année, January 7-14, 1906, p. 3 ; also ibid., no 272 , January $1-7,1906$, p. 3. 
reported that in the forefront of the campaign was the Metal Workers' Union, and said: "I consider Merrheim the most serious of all. [...] he strikes me as a man of great sincerity". He observed, however, that Merrheim suffered from neurasthenia and was "grieved having too often seen his campaigns lead to nothing". ${ }^{1}$ This was the first indication that Merrheim suffered from nervous exhaustion because of overwork or prolonged mental strain, a condition, unfortunately, which became worse.

Meanwhile, the national campaign reached its height in April-May, 1906, against the background of a miners strike in the Nord and the Pas-de-Calais. The CGT's "Conference of the Federations" met in April to conclude its preparations. There, however, militants disagreed over the strategy to follow and pointed out that trouble had developed in the plans for May Day. Despite an auspicious beginning, the campaign's subsequent lack of progress in the steel industry displeased a secretary of the Federation of Metal Workers, Jean Latapie, ${ }^{3}$ and Struck of the Machinists' Union criticized the Metal Workers' Union for lack of full support. He also preferred a ten-hour day. Many workers, he explained, worked eleven hours; for them an eight-hour day was an unreasonable expectation. ${ }^{4}$ Furthermore, some syndicalists wanted a complete work-stoppage on May 1, while others wanted the strike postponed to May 2 if talks with employers on May 1 failed. ${ }^{5}$ Others, on the other hand, wondered whether the campaign would get off the ground. ${ }^{6}$ Merrheim, too, expressed reservations. First, he defended the full commitment of Latapie and the Metal Workers' Union, even when they questioned which centers of the steel industry would agitate. They were not, he said, prophets. Moreover, he reported that distrust existed in some locals and blamed the lack of efficient propaganda by the central organizations. ${ }^{7}$ Many workers, he concluded, had lost confidence in the campaign. ${ }^{8}$ The outcome of the Conference of Federations was also negative, and its resolutions reflected the CGT's ambivalence and diminished enthusiasm. ${ }^{9}$ For example, the conference

1 AN, F 7, 12890, January 19, 1906, 4,656.

${ }^{2}$ Conférence des Fédérations. Journées des 5 et 6 Avril 1906 (Brochure 8º, 40 pp., n.d.).

${ }^{3}$ Ibid., pp. 11-13.

4 Ibid., pp. 18-19.

5 Ibid., pp. $27-28$; p. 31.

Ibid., pp. 6-7; pp. 8-9.

7 Ibid., pp. 19-20.

8 Ibid., pp. 33-34.

9 Ibid., pp. 39-40. See also "Résolutions de la Conférence des Fédérations", in: La Voix du Peuple, no 287, 6e année, April 15-21, 1906, p. 1. 
called for strong worker demonstrations but suggested two tactics: On May 1 workers could stop working after eight hours, or not work at all that day.

The divisions manifested at the conference threatened to undercut Merrheim and the CGT. They had prepared a campaign for two years only to doubt its outcome. In such a context, the CGT's varied composition might hurt the organization. It contained reformers and revolutionaries, and the former preferred to agitate through the existing political machinery while the latter favored direct economic action. Both factions frequently suggested dissimilar measures for a similar problem, but even when they agreed, diverse industrial conditions throughout France made centralized coordination of demonstrations difficult.

Moreover, the government added to the CGT's difficulties. Georges Clemenceau, the Minister of the Interior from March to October 1906, began transforming Paris into an armed camp by bringing in approximately 60,000 soldiers. Clemenceau capitalized on the labor agitation which intensified as May 1 drew near. In March, 1906, an accident in the mining area of northern France killed a worker, and a violent strike resulted which further added to the growing unrest. The postmen struck in April, leading off other strikes and demonstrations in Paris, and enemies of the government, especially the monarchists, exploited these problems. Clemenceau tried to discredit the eight-hour movement by "discovering" a plot by the monarchists and the CGT against the Republic. The government searched the homes of leading monarchists, Bonapartists, and revolutionary syndicalists, and on the eve of May 1, arrested, for a few days, monarchist and syndicalist leaders including Pouget, Merrheim, Gaston Lévy, the CGT Treasurer, and Victor Griffuelhes, Secretary-General of the CGT.

\section{The Beginning of the Hennebont Strike}

Nevertheless, in May, 1906, the CGT struck for the eight-hour work day. Some tactical divisions and the attempted government repression could not halt the undertaking. According to plan, each federation secretary was responsible for coordinating a strike in a particular section of France, and Merrheim led the metal workers of Hennebont.

A city of 8,074 in 1906, Hennebont is in the canton of Morbihan in the district of Lorient in southwest Brittany. The Compagnie Française

1 The first formal study of this strike was by Alphonse Merrheim, "Un Grand Conflit Social: La Grève d'Hennebont", part I, in: Le Mouvement Socialiste, IIe Série, VIIIe année, no 180, November, 1906, pp. 194-218; part II, ibid., no 181 , December, 1906 , pp. 347-379. Hereafter cited as "Un Grand Conflit Social", I and II. 
des Cirages (French Wax Works Company), with headquarters in Paris, established forges for making wax there. Merrheim wrote that the company whose production steadily increased between 1861 and 1905 had never adequately raised workers' wages to meet the rising cost of living. ${ }^{1}$ As a result, conflicts between labor and management broke out: In a 1902 strike in the district, Jean Latapie, Henri Galantus, and Albert Bourchet of the Metal and Copper Workers' Unions had already organized workers. ${ }^{2}$ Bad conditions continued, however, making the area ripe for revolutionary syndicalist propaganda. Morbihan also figured in the CGT's plans for the May Day agitation. In December, 1905, for example, Hennebont workers demanded a wage increase beginning on January 1, 1906. And, by December, 1905, Merrheim, Yvetot, and other CGT representatives propagandized in Hennebont, making workers there more receptive to revolutionary action and causing them to heed CGT plans and orders for May $1 .^{\mathbf{3}}$

In Morbihan the eight-hour day strikes began before May 1. Events were precipitated by workers in Hennebont's neighbor city of Lorient. By April 3, members of the Bourse du Travail of Lorient, preparing for May 1, had already demonstrated and called for assistance from the CGT.4 A police spy observed there was much ferment there by April 10. He noted further that Merrheim held meetings to obtain support for the strike. ${ }^{5}$ Lorientian workers, as they indicated to Jacques Giband, mayor of Hennebont and director of the French Wax Works, wanted higher wages, suppression of piece work, aind the eight-hour day. Giband forwarded the demands to Paris, believed the company would reject them, and concluded that there would be "an extremely serious conflict". ${ }^{6}$ Hennebont syndicalists, in close touch with other Morbihan workers, ${ }^{7}$ also demonstrated. On Saturday, April 14, the

1 "Un Grand Conflit Social", I, pp. 197-198.

2 Ibid., pp. 202-207.

3 AN, F 7, 12765, Hennebont, December 11, 1905 (dossier "Morbihan").

4 AN, F 7, 12786, April 4, 1906 (dossier "Lorient").

5 Ibid., April 10, 1906.

${ }^{6}$ This information is contained in a letter, dated April 9, 1906, Giband sent to the commissioner of police of Hennebont. Since Giband feared trouble, he requested forces to maintain public order. The letter is in AN, F6, 12786, April 11, 1906 (dossier "prefects reports").

? For just a few examples of leaders going back and forth between Lorient and Hennebont before the strike see: AN, F7, 12786, April 17, 1906, April 24, 1906, and especially April 18, 1906 (dossier "Lorient"). The last report deals with a Lorient meeting at which a delegate of the CGT, Pommier, spoke. He had toured the area and reported on Hennebont. The workers there, he said, could not strike until they received a final response to their demands from the company. A local leader, however, reported that the Hennebont workers had already voted to support the Lorient workers and had formed an entente for that purpose. 
Hennebont union presented its demands to Giband, ${ }^{1}$ which amounted to increased wages, a daily rest period, two work shifts, and the eighthour work day. Giband doubted their realization but promised to present them personally to company heads in Paris and return with an answer on April 23. The Hennebont commissioner of police believed workers would strike for their claims, ${ }^{2}$ and other reports corroborated his estimation. ${ }^{3}$ The commissioner's predication materialized on April 23. On April 19, Lorientian workers called a general strike and hoped Hennebont workers would follow. 4 The Hennebont workers, meeting on April 22, decided to wait for Giband's reply. ${ }^{5}$ They received his negative response at their Monday, April 23, meeting, ${ }^{6}$ where, by a vote of 630 for, 490 against, and 52 blank votes, they decided to strike. ${ }^{7}$

The CGT's first delegate to Lorient and Hennebont, Sélaquet, a metal worker and Bourse du Travail representative, arrived in Hennebont on April 27.8 $\mathrm{He}$ insisted that the men achieve the eight-hour day with no decrease in wages. ${ }^{9}$ On another occasion he warned the strikers to prepare "for long days of suffering and resistance". Blood might

1 AN, F 7, 12786, Hennebont, April 15, 1906.

2 Ibid.

3 See p. 170 , note 7.

4 AN, F7, 12786, Lorient, April 17, 1906. Also see AN, F 7, 12886, Lorient, April 22, 1906. The latter report states that Jacoby, a CGT delegate, and Crainac, a militant, have left Lorient for Hennebont to confer with the workers of the forges. The report predicts that the Hennebont workers will strike on April 23 at 6 a.m. There was another more precise report on this meeting: see AN, F 7, 12786, April 22, 1906 (Paris, "prefect to Interior cabinet", Dossier "prefect"). This note stated that Jacoby addressed a meeting of about 600 workers where demands were read. Jacoby, a woman, also persuaded the women of Hennebont to take part in the strike. Then Crainac followed and called for a general strike. The workers, however, decided to wait until the following day, April 23, in order to receive Giband's final answer. The report concluded that a strike appeared imminent.

5 AN, F7, 12786, April 22, 1906 ("prefect"). Two reports in this dossier discuss this meeting.

- There is a series of reports which deal with this meeting, some more detailed than others. See, for example, AN, F 7, 12786, April 23, 1906 (from "préfet à Commerce et Intérieur"), and Hennebont, April 23, 1906. The most satisfactory and detailed reports, however, are those of Vannes, April 26, 1906.

7 Although the strike broke out before May 1, there is no doubt that it was part of the CGT's eight-hour day movement. See Union Fédérale des Ouvriers Métallurgistes, XIIIe Congrès National des Ouvriers Métallurgistes - Compte Rendu des Travaux du Comité Fédéral (Bourges, 1908), pp. 22-23.

${ }^{8}$ AN, F7, 12786, Vannes, April 28, 1906.

9 For Sélaquet's first meetings see AN, F7, 12786, Vannes, April 30, 1906 (two reports with the same date); Hennebont, April 30, 1906, and Hennebont, May 1, 1906. 
flow, he said, but the leaders would back the strikers with their presence. ${ }^{1}$ On May 3, Giband posted an open letter warning that the factory might be closed and advising workers to seek jobs elsewhere if they wished. ${ }^{2}$ Yet the letter, which "produced a very great impression", made the strikers more aggressive and determined. ${ }^{3}$ Sélaquet dismissed Giband's threat, informed the strikers that the union would give them bread, and concluded that "the strike is our legitimate force". ${ }^{4}$ The company, on the other hand, blamed outsiders like Sélaquet for the troubles. ${ }^{5}$ When the appeal to provincial distaste for outsiders failed to deter workers, Giband's police arrested Sélaquet. The strikers, now adamant, wired to Paris for another leader. ${ }^{6}$ Alphonse Merrheim came. $^{?}$

\section{Merrheim's Problems: Company Tactics and the Syndicalist Variety}

In Hennebont Mierrheim faced a strong, unsympathetic company which had ties with the government. Jacques Giband fought the strikers with public power. For example, Merrheim suspected that Giband wanted to destroy the "red union" and was responsible for Sélaquet's arrest. Moreover, he charged Giband with asking store owners in Hennebont to refuse credit to the strikers. ${ }^{8}$ He also noted that Giband was trying to block the union's attempt to distribute food to hungry workers. ${ }^{9}$ The company employed strike breakers as well. From the very outset a group of workers was hostile to the strike. One police report stated, "The struggle continues to be lively at Hennebont between the partisans of the strike and the numerous workers who are hostile to it. The idea of a referendum remains ever present. For their part the delegates are doing all they can to bring the workers to strike." The company used this split as a wedge to break the strike. In one instance, it secured the services as company foreman of Kerbastard, the secretary

1 AN, F 7, 12786, Hennebont, May 2, 1906.

2 AN, F 7, 12786, Hennebont, May 3, 1906.

3 Ibid.

4 AN, F 7, 12786, Hennebont, May 4, 1906.

5 To trace these events see AN, F 7, 12786. This goldmine of information contains daily police reports on events.

- AN, F 7, 12786, Hennebont, May 17, 1906.

7 AN, F 7, 12786, Hennebont, May 26, 1906. Merrheim did not arrive on time and the next few meetings were taken over by others. See Hennebont, June 1, 1906.

"Alphonse Merrheim, "A Hennebont", in: L'Ouvrier Métallurgiste, 16e année, no 176 , July 1,1906 , p. 1.

${ }^{8}$ L'Ouvrier Métallurgiste, 16e année, no 177, August 1, 1906, p. 3. Alphonse Merrheim, "A Hennebont", in: La Voix du Peuple, no 301, 6e année, July 15-22, 1906, p. 2. 
of the Hennebont union. Kerbastard returned to work with twentyeight other strikers, ${ }^{\mathbf{1}}$ and Merrheim admitted that this action convinced employers the strike could not last. ${ }^{2}$ The company also wore workers down by rejecting their claims while simultaneously opening the factory to those who wished to return. Furthermore, in mid-June, Giband wrote to each worker, implying that he should return by July 15, the day on which Giband opened a register for the resumption of work. ${ }^{3}$ Merrheim countered by saying that Giband was begging workers to return. ${ }^{4}$ Giband won, however. Many who had not worked for three months gave up, and the prefect's daily reports from mid-July on are often only a steadily increasing count of strikers resuming work. ${ }^{5}$ This development demoralized many and violent clashes between strikers and strike breakers and their families broke out. ${ }^{6}$

In one instance Giband's measures against workers so threatened the peace that even Hennebont's prefect objected. At the end of June, Giband began loading a barge with iron as if business were normal. Workers took this as a defiant and insensitive gesture, for at issue was whether Giband would move the barge. Workers, police, and troops anxiously milled about the boat. The prefect of police warned Giband that moving the barge would mean trouble; he then wired to Paris that Giband was purposely forcing an incident. Finally, on July 10, the prefect of Hennebont suspended Giband from his post as mayor,

${ }^{1}$ For the report and information on Kerbastard see AN, F7, 12786, Lorient, April 27, 1906.

2 Alphonse Merrheim, "Au Pilori!: Kerbastard transfuge”, in: L'Ouvrier Métallurgiste, 16e année, no 177, August 1, 1906, p. 2. See also Alphonse Merrheim, "La Grève d'Hennebont", in: La Voix du Peuple, no 303, 6e année, July 29 August 5, 1906, p. 2.

3 The process by which the company instituted this tactic was drawn out. The idea to open the factory to those who wished to return was first mentioned early in July. During the rest of the month Giband issued letters and manifestoes, the union answered him, and several strikers began returning to work. For much of this information which I have pieced together, see the following: AN, F7, 12786, Rapport, Lorient, June 6, 1906; AN, F7, 12786, Hennebont, July 13, 1906; Alphonse Merrheim, "A Hennebont", in: La Voix du Peuple, loc. cit.; AN, F7, 12786, June 9, 1906; and AN, F 7, 12786, Hennebont, June 12, 1906. 4 See AN, F 7, 12786, Hennebont, June 15, 1906.

5 The reader's attention is called to AN, F7, 12786, where the prefect of Hennebont issued daily reports to his superiors in Paris on the local situation. Follow the reports from July 15 on to trace the count of men returning to work.

- Homes of some of the strike breakers were set afire. In another instance the wife of one man on the job was attacked by the wives of two strikers. Also, a strike breaker's child was hit by strikers. See, for example, AN, F 7, 12786, Vannes, July 20, 1906; Hennebont, July 20, 1906; Hennebont, August 6, 1906; Hennebont, August 7, 1906; and Hennebont, August 8, 1906. 
charging that he abused public office for company business. ${ }^{1}$ The barge remained in port and the prefect averted trouble.

While conducting the strike, Merrheim also had to contend with federation business in Paris, opposition from non-union workers, and the hostility some strikers felt towards him as an "outsider". Merrheim had to describe how he directed both the strike and his federation in response to accusations that he travelled second rather than third class on train trips from Paris to Hennebont. ${ }^{2}$ On Thursday, he left Hennebont at 9 p.m., arriving in Paris at 11 a.m.; Friday morning he answered federation correspondence; Friday evening he attended a meeting of the federal committee till midnight. On Saturday, he handled more federation business until 9 p.m., then left Paris for Hennebont. This pace, he wrote, deserved riding in comfort. On the other hand, a non-union worker expressed the hostility some provincials felt toward syndicalist leaders from Paris. On June 5, 1906, a non-union truck driver, addressing a meeting in the town of Garode, ${ }^{3}$ stated that he left the union when he saw his dues "fatten the good-fornothings of the confederation". ${ }^{4} \mathrm{He}$ also attacked the strike committee for continuing a seemingly futile strike. Moreover, he complained that Hennebont workers did not need the services "of strangers for talks with employers". 5

\section{Merrheim and the Conduct of the Strike}

Merrheim remained firm before such obstacles. He was never a more tenacious labor leader than in the Hennebont strike. He insisted on the eight-hour day or at least a modicum of reform for the Hennebont strikers, but the company gave nothing. Under these conditions, he

1 AN, F 7, 12786, Vannes, June 24, 1906; Lorient, July 6, 1906; Vannes, July 9, 1906; Hennebont, July 10, 1906; and, also found in ibid., the journal Action for July 13, 1906. The suspension was lifted on August 10, when the strike was almost over.

2 XIIIe Congrès National des Ouvriers Métallurgistes, op. cit., pp. 226-227.

${ }^{3}$ Details of this meeting, which is better covered than most, are in AN, F7, 12786, Hennebont, June 5, 1906 (from the Commissioner of Police of Hennebont to the Prefect of Morbihan).

4 Ibid.

${ }^{5}$ Ibid. Moreover, Merrheim answered a charge about receiving as a CGT functionary a large monthly wage, 250 francs, while directing the strike by stating that he would have received 300 francs per month if he had remained a practicing copper worker. He continued, somewhat apologetically, that he had no children, his wife earned three francs a day, and he paid all his debts. He could not deny receiving high wages while others were unemployed, however. He presented the argument that the overall interests of syndicalism required that leaders get paid and that strikers, too, would ultimately benefit. 
suggested violence as a possible tactic for workers, although he never lost sight of the strikers' limited goals. To obtain these he would threaten to use force but he was also willing to negotiate with employers and the government.

Several reasons led Merrheim to believe that the workers should obtain their demands. Their strike was part of a nationally directed CGT campaign, whose wide support encouraged federation leaders. Also the Hennebont strikers had been out for over forty days. Should they return without any gains, their position, Merrheim knew, would be worse than before the strike. Their union, for example, would be morally and financially bankrupt. Consequently, upon arriving in Hennebont, Merrheim immediately attended a morning session of the strike committee for information, and he held his first union meeting at 1 p.m. the same day (June 2). ${ }^{1}$ Beginning with typical trade union oratory, he briefly reviewed the company's economic status, and demonstrated it could afford higher wages. Moreover, workers for the Compagnie Française des Cirages at Saint-Ouen, he said, had already received wage increases and the nine-hour day. The company, he believed, could grant similar reforms to the Hennebont workers. In any case, he believed the forty-two-day-old strike must continue because workers had gained nothing yet. To give up now, Merrheim warned, would place workers at the mercy of the employers, for the company might make them work ten hours. Workers should also salvage something for their many sacrifices. ${ }^{2}$ A police spy wrote that Merrheim stated the strike should continue until workers "have obtained all or part of their claims". ${ }^{3}$ Merrheim's belief that the strike was morally correct made him firm, and he advised workers to trust the union in spite of Kerbastard's defection. They should remain united and "not return to work with lowered heads". 4 Also, when he arrived at Hennebont, he believed that the strike would end in two weeks. ${ }^{5}$ Consequently, he repeated the advice to hold firm.

Police observers noticed Merrheim's determination to settle the strike fairly, but their reports noted too the pressures which frequently upset him. One document stated that he and Latapie worked endlessly

${ }^{1}$ Le Nouvelliste du Morbihan, June 7, 1906.

${ }^{2}$ AN, F7, 12786, Hennebont, June 2, 1906 (from the Commissioner of Police of Hennebont to the Prefect of Morbihan at Vannes).

${ }^{3}$ AN, F 7, 12786, Hennebont, June 2, 1906 (from the Prefect of Morbihan to "Intérieur, Cabinet et Sûreté, Paris").

4 AN, F 7, 12786, Hennebont, June 2, 1906.

${ }^{5}$ When Merrheim arrived in Hennebont, he indicated that since the strikers had modified their demands, the company would probably accept them within two weeks. See note 2 . 
for the strikers, "facilitating [...] the solution of numerous conflicts between the employers and the proletariat". ${ }^{1}$ When Merrheim had gained nothing by mid-June, however, he became "more violent than usual against capitalism and the employer class, and incidently engaged in an anti-militarist tirade". ${ }^{2}$ In another instance, Merrheim insisted that workers remain steadfast and angrily discounted rumors that the strike committee's finances were giving out or that it would soon cease its bread distributions. ${ }^{3}$ His speech heartened the weary workers who voted to continue the strike. ${ }^{4}$ The company's desire to destroy the union made Merrheim's speeches unusually forceful.

Such campaigns harried Merrheim, and government pressure adversely affected him. In Paris, Clemenceau arrested him and other CGT leaders for a few days in an attempt to break the May Day movement. ${ }^{5}$ In Hennebont, local officials began a legal indictment against Merrheim for "provocations against the military". ${ }^{6}$ Clemenceau also had a man spy on Merrheim. The dossier his spy sent to Paris is informative, ${ }^{7}$ for it confirmed that the prosecutor of Lorient indicted Merrheim "for having made several revolutionary speeches". In addition, it stated that before the Hennebont strike, Merrheim was known "as a prudent man, incapable of being carried along to commit a misdemeanor", and that Merrheim worried about the charges against

1 AN, F7, 13771 (le mouvement syndical dans la métallurgie (historique), n.d.). 2 AN, F 7, 12786, Hennebont, June 10, 1906. The same report went on to offer an explanation for this violence. "One attributes his violent language to his anger: he has alluded to his arrest several times." It makes no sense to say, as the report does, that Merrheim was more violent because he hoped for amnesty. This also does not take into consideration the effect he would have produced on his audience, something of which he was aware. His possible arrest was a real threat, however, as the reader shall see in the rest of the narrative.

${ }^{3}$ AN, F 7, 12786, Hennebont, June 19, 1906.

4 Another report along the same lines is rather revealing. It is in the Police Archives and is a biographical sketch of Merrheim up to 1907. Concerning his Hennebont activities the report said, "He [Merrheim] is considered at the Bourse $d u$ Travail and in workers' organizations as a militant syndicalist and he is often picked to conduct conferences in the provinces. Thus, last year in April, he went to Denain for several meetings. A little later in June, he went every fifteen days among the Hennebont strikers to exhort them to continue the strike. His language is rather violent and he called himself a partisan of direct action." See Archives de la Préfecture de Police de Paris, B/a 1686, March, 1907 ("Au Sujet de la Confédération du Travail - Ses Effectifs - Son Comité - Renseignements sur les Principaux Membres de ce Comité", Dossier 1).

${ }^{5}$ Merrheim's only comment when in Hennebont was to excuse himself for being late because, he said, the government accused him of being mixed up in a plot and he could not leave Paris. See AN, F7, 12786, Hennebont, June 2, 1906.

${ }^{6}$ AN, F7, 12786, Vannes, June 22, 1906.

$7 \mathrm{AN}, \mathrm{F} 7,13772$, Paris, June 28, 1906, M/1268. 
him. Merrheim even talked to Clemenceau about his possible arrest, telling the minister that the police were hounding him out of revenge and that the union's struggle against oppression was not a misdemeanor. ${ }^{1}$ The report concluded that another federation official had to temporarily replace Merrheim, who was too harassed to continue without a rest. No wonder another spy wrote that Merrheim "was very worried at not being able to clearly see a solution" and warned that the strike might end in violence. ${ }^{2}$

Merrheim's meeting with Clemenceau is interesting because it illustrates - no matter what spies wrote about violence - Merrheim's concern for his personal safety and his fear of governmental power. Moreover, it demonstrated Merrheim's willingness to negotiate with the "enemy class". ${ }^{3}$ The Hennebont strike concerned Clemenceau because, like others of its length, it was potentially dangerous. On June 7 , the minister sent an aide to Hennebont for information. ${ }^{4}$ On July 3, Clemenceau and the prefect of Morbihan arranged a meeting between four union representatives, Giband, and company representatives. ${ }^{5}$ Although the meeting was inconclusive and Giband refused to yield, ${ }^{6}$ L'Humanité, the official journal of the SFIO, praised Clemenceau's mediation efforts. ${ }^{7}$ Merrheim also met with Clemenceau on behalf of the strikers. On July 25 and 26, for instance, he tried to have the minister prevent "police brutalities" in Hennebont. 8

1 Ibid.

2 This information is from the secret report of "A Correspondent", found in AN, F7, 12786, June 14, 1906.

3 Not only would Merrheim have to negotiate with capitalists to end the strike, but syndicalists sought the active cooperation of socialists. Syndicalists did not agree with socialists on many social issues but could use the latter's help. See AN, F 7, 12786, July 2, August 9 and August 10, 1906. The last two reports state that because the socialists intervened, the Minister of War granted a reprieve of twenty-eight days to all strikers being called for military instruction. He did this because he acknowledged that the strike resulted in hardship for the workers. A socialist deputy was instrumental in the reprieve, but syndicalists did not revise their negative estimation and distrust of all political parties.

" Merrheim, "Un Grand Conflit Social", II, p. 355.

5 There are several sources for this meeting. See L'Humanité, no 808, July 4, 1906, p. 2, and no 809, July 5, 1906, p. 2; AN, F7, 12786, July 5, 1906; Merrheim, "Un Grand Conflit Social", II, pp. 359-361; and especially Le Nouvelliste du Morbihan, July 8,1906 , which is more detailed than the other sources.

- See Le Nouvelliste du Morbihan, July 8, 1906, and Merrheim, "Un Grand Conflit Social", II, pp. 360-361.

7 L'Humanité, no 809, July 5, 1906, p. 2.

${ }^{8}$ Merrheim never mentioned his meeting with Clemenceau in his formal study of the Hennebont strike, and there is not much information on precisely what he and the minister talked about. However, during one trip to Paris he did apparently talk to Clemenceau about "police brutalities" in Hennebont. This very 


\section{Merrheim and the End of the Strike}

In spite of the strike, Clemenceau's intervention, and Merrheim's willingness to compromise, the company refused to make any concessions. Giband wanted to break the strike and destroy the revolutionary syndicalist union. For his part, Merrheim knew that the strike could not go on much longer, since many strikers had already returned to work. He insisted that the strike continue, however, so workers might gain some reform and keep their union intact. During the last two weeks of the strike, therefore, he alternated negotiations with threats of force. ${ }^{1}$

When Giband's wish that full work resume on August 1 did not materialize, he ordered strikers to vacate their company-owned homes within a week. ${ }^{2}$ On the same day, however, Merrheim ordered workers to continue striking, ${ }^{3}$ and he reasserted his determination at union meetings on August 2, 3, and 4. ${ }^{4}$ On August 5, desperate and frustrated, Merrheim was "especially violent in order to spur the workers to continue the strike and to oppose, with violence if necessary, the resumption of work". ${ }^{5}$ On another occasion he told workers to block the factory's entrance, even if blood had to flow. ${ }^{6}$ They did so, but police dispersed them. ${ }^{7}$ In "the name of humanity" he implored strikers

fragmentary information is contained in two telegrams sent by Merrheim from Paris to Hennebont. One is dated July 24, 1906, and the other July 25, 1906; both are in AN, F 7, 12786. Merrheim went to Paris frequently to attend to federation business during the strike. However, he also tried to help the Hennebont strikers from Paris; Clemenceau was in Paris and so was the headquarters of the Compagnie Française des Cirages. Shortly after the above meeting he was called back to Hennebont, where he urged that the strike continue because the workers had gained nothing from the company yet. See Merrheim, "Un Grand Conflit Social', II, p. 367; and AN, F 7, 12786, Hennebont, July 29, 1906, and July, 31, 1906.

1 Merrheim's account in "Un Grand Conflit Social", II, pp. 367-373, agrees in all its essentials with police reports being filed during the events. Moreover, Merrheim admitted that his call for an end to the strike was unpopular with many workers.

2 For a reprint of this letter, see Alphonse Merrheim, "A Hennebont", in: La Voix du Peuple, no 304, 6e année, August 5-12, 1906, p. 2, and "Un Grand Conflit Social", II, p. 368.

3 AN, F 7, 12786, Hennebont, August 2, 1906.

4 AN, F 7, 12786, Hennebont, August 2, 1906, Hennebont, August 3, 1906, and Hennebont, August 4, 1906.

5 AN, F 7, 12786, Hennebont, August 5, 1906.

- AN, F 7, 12786, Hennebont, August 5, 1906 (two reports with the same date); AN, F7, 13772, August 5 [1906] (Dossier - Union Fédérale des Ouvriers Métallurgistes, 1906, pp. 12-26).

7 AN, F7, 13772, August 6 [1906] (Dossier - Union Fédérale des Ouvriers Métallurgistes, 1906, pp. 12-25). 
not to return with a "lowered head". ${ }^{1}$ For their part, strikers attacked the homes of strike breakers, and on the night of August 6, several fires broke out in Hennebont. The prefect called Merrheim to the city hall, blamed him for the fires, and threatened to arrest him. ${ }^{2}$ At this time, Merrheim suggested that a workers' delegation talk to the prefect about strike matters. ${ }^{3}$ Finally, on August 8, talks resumed between union and company officials. This time Giband promised to raise wages, to try the eight-hour day, and to recognize the revolutionary syndicalist union. ${ }^{4}$ He refused to write this out, however, insisting that the strike committee trust him. The committee, in a weak position, accepted Giband's condition. Then Giband posted a notice stating that he promised to "alleviate" not "augment" wages, that any changes must not reduce the company's profits, ${ }^{5}$ and that his terms were unnegotiable. ${ }^{6}$ This was Giband's manner of indicating he would not raise wages if they cut into company profits. Furthermore, the company would not rehire all strikers. ${ }^{7}$ On this point, though, Merrheim and union leaders reduced the list of strikers not being rehired from 150 to 10 ; the latter had found jobs elsewhere.

Since the company would go no further and additional union force was useless, Merrheim admitted defeat and ended the strike, although a large minority of workers wanted to continue. On the morning of August 12, the union held a vote. Out of 1600 union members, only 750 voted, with 605 for and 145 against continuation. ${ }^{8}$ In an afternoon meeting, Merrheim and the strike committee announced the results and their own decision to end the strike, ${ }^{9}$ which could not continue with a minority of the company's workers, they said. The strike was over, "Long live the Strike", ${ }^{10}$ but "this declaration was greeted with grumbling by the men and violent protests by the women", Merrheim wrote later. ${ }^{11} \mathrm{He}$ noted, however, that prolonging the strike was im-

1 AN, F 7, 12786, Hennebont, August 4, 1906.

2 Merrheim, "Un Grand Conflit Social", II, pp. 368-369, and L'Humanité, August 9, 1906, p. 1.

3 AN, F 7, 12786, Hennebont, August 6, 1906.

4 Full details of the meeting at which these terms were agreed upon are in AN, F7, 12786, Hennebont, August 9, 1906. A full list of the terms of the settlement is given in Merrheim, "Un Grand Conflit Social", II, pp. 369-370.

"For a copy of this poster, entitled "Avis Aux Ouvriers des Forges d'Hennebont", see AN, F7, 12786 (n.d., in the dossier from the prefect of Morbihan to the Minister of the Interior, dated August 12, 1906).

- AN, F7, 12786, Hennebont, August 10, 1906.

7 AN, F 7, 12786, see the meetings for August 10 and 11, 1906.

- AN, F7, 12786, Hennebont, August 12, 1906.

${ }^{2}$ Ibid., and Merrheim, "Un Grand Conflit Social”, II, pp. 371-373.

${ }_{10}$ AN, F7, 12786, Hennebont, August 12, 1906.

11 Merrheim, "Un Grand Conflit Social", II, p. 372. 
possible and would have completely destroyed the union. ${ }^{1}$ On the evening of August 12, he delivered the strike committee's extremely unpopular decision to end the conflict. ${ }^{2}$

In spite of this definitive defeat at Hennebont, Merrheim's syndicalist beliefs made him optimistic, for he believed, along with other revolutionary syndicalists, that one day a workers' general strike would overthrow capitalism. The syndicalist movement would have to prepare for that eventuality by strengthening the workers through social reforms and by creating in them a revolutionary class consciousness through education. Merrheim's goal was far off, therefore, and this made him regard all gains as important and setbacks as temporary. Furthermore, he did not permit himself outward sentimentality before the tasks at hand. Thus, he bade farewell to the strikers dispassionately. $^{3}$ "In spite of your 111-day struggle, your sufferings and privations, the fight is not over. Everything must begin anew tomorrow morning". ${ }^{4}$ In addition, strikers should remain united, he said, because "you are the avant-garde of the proletariat". ${ }^{5}$ Finally, he urged the workers to maintain their revolutionary consciousness and to "raise your children with revolutionary ideas so that they may be free men while waiting for the transformation of society [...] hope for more justice and live for a future of greater freedom". ${ }^{6}$

Merrheim was relatively satisfied with the outcome of the strike. $\mathrm{He}$ believed it had radicalized its participants, ${ }^{7}$ an important function of the strike, since radicalization would contribute to the ultimate syndicalist victory. And the introduction of revolutionary consciousness into the Hennebont area far outweighed the apparent failure. The Hennebont strikers, he wrote, would not forget "that the Republic is no better than any other social regime". It grants the worker some education but establishes "economic repression". ${ }^{8}$ The CGT, also, was confident and impressed with the large turnout on May 1, for it, too, believed that revolutionary syndicalist ideas had spread, since a large number of workers had recently joined the CGT. ${ }^{9}$

1 Ibid.

2 Ibid.

${ }^{3}$ This speech is in AN, F 7, 12786, Hennebont, August 12, 1906.

${ }^{4}$ Ibid.

5 Ibid.

6 Ibid.

7 Ibid.

8 Merrheim, "Un Grand Conflit Social", II, pp. 377-378. For the overall conclusions, see ibid., pp. 375-379.

9 Louis Levine, The Labor Movement in France (New York, 1913), p. 169; see ibid., pp. 375-379. 
This optimism was short-lived and unrealistic, however. In October 1906, Georges Clemenceau became premier (1906-1909). He increased the harassment of syndicalists and granted more power to the police which became increasingly arbitrary towards syndicalists and stepped up their spying program within the CGT. ${ }^{1}$ Clemenceau also used soldiers to break CGT strikes forcibly, most notably in June, 1907, among wine-producers in southern France and in June-August, 1908, among building-trades workers in Draveil. ${ }^{2}$ In both instances, the CGT gave in to the government. After the 1907 strike, Victor Griffuelhes, Secretary-General of the CGT, commented that a "momentary fatigue" gripped the CGT. ${ }^{3}$ After the Draveil strike, Clemenceau arrested the CGT's secretaries, thereby causing a serious break in the organization's ranks as syndicalists vied for the open positions. In addition, Griffuelhes became implicated in 1909 in financial irregularities associated with his purchase of a new CGT headquarters. The ensuing scandal forced him to resign as secretary-general of the CGT in February, 1909. At this time reformist and revolutionary factions in the CGT attacked each other openly and Merrheim's article, "The Syndicalist Crisis", summed up the confederation's hard times, ${ }^{4}$ which affected him too. In 1907 the Federation of Metal Workers expressed disappointment over the 1906 strikes and reported they had strained its financial resources. ${ }^{5}$ Between 1907 and 1909, the federation underwent factional disputes, and its leaders fell out with one another. In 1909, Merrheim also figured prominently in the struggle for control of the CGT. When Merrheim estimated the importance of the 1906 movement seven years after the event in 1913, he concluded simply that "May 1, 1906 had been a lesson of consciousness and will whose fruits we shall gather slowly but surely in the future."6

More important in the context of these difficulties, however, was Merrheim's peculiar fusion of theory and practice which blunted his revolutionary capacity, a characteristic that becomes clear after 1906 . Merrheim's revolutionary syndicalist attitude was determined largely

1 "Les Policiers dans les Syndicats", in: La Voix du Peuple, no 294, 6e année, May 27 and June 3, 1906, p. 1.

2 Cf. Clemenceau Briseur de Grèves: L'Affaire de Draveil-Villeneuve-SaintGeorges, présentée par Jacques Julliard [Collection Archives] (Paris, 1965).

3 "Confédération Générale du Travail - Section des Fédérations - [ProcèsVerbal de la] Séance du 23 Décembre, 1907", in: La Voix du Peuple, no 400, 8 e année, May 31 and June 7, 1908, p. 4.

"Alphonse Merrheim, "La Crise Syndicaliste", in: Le Mouvement Socialiste, nos 215 and 216, November-December, 1909, pp. 291-299.

5 XIIIe Congrès National des Ouvriers Métallurgistes, op. cit., pp. 23-25.

- Alphonse Merrheim, La Métallurgie (Paris: Edition de la Fédération des Métaux, 1913), p. 405. 
by his participation in trade union activities, especially strikes. Here Merrheim began to glean that syndicalists faced a powerful employer class and government. It remained for him to learn exactly how powerful and what course revolutionary syndicalism should take.

$\mathrm{He}$ began to answer these questions after his participation in the strikes of Cluses, Longwy, and Hennebont. Merrheim's study of the strike at Cluses is not technically sophisticated. It consisted of a series of articles reporting the events and Merrheim's outraged reaction to them. ${ }^{1}$ At Longwy Merrheim realized he did not have the knowledge necessary to understand the international cartel that controlled the area. He found and read carefully, therefore, a work on the Longwy economy written by the economist Francis Delaisi. ${ }^{2}$ When Merrheim wrote his own study on Longwy it was far superior to his work on Cluses. ${ }^{3}$ Yet by the time he arrived at Hennebont his knowledge of technical reports still was limited. He stated that in 1907 steel barons from Germany, Great Britain, and Italy, all members of an international cartel, had met in Paris. He wrote that "We [the syndicalists] had to follow their discussions and to examine their reports. I actually had to go to a mining engineer to learn how to read financial reports". ${ }^{4}$ At Hennebont Merrheim, as a member of the coal-workers strike committee, talked with a company engineer, whose financial accounts completely baffled him. Remembering Delaisi's study on Longwy, Merrheim looked him up personally for information and assistance. ${ }^{5}$ A life-long collaboration between them began which culminated in Merrheim's published studies on the French steel industry, which attest to his complete mastery of the technical and financial workings

1 For his most important articles on Cluses see the following issues of La Voix du Peuple: no 200, August 14-21, 1904, pp. 1-2; no 204, September 11-18, 1904, pp. $1-2$; no 208 , October $9-16,1904$, p. 1 ; no 209 , October $16-23,1904$, p. 1 ; no 212, November 6-13, 1904, p. 1; no 213, November 13-20, 1904, pp. 1-2; and no 216, December 4-11, 1904, p. 2. See also his articles on the strike at Cluses in the following issues of L'Ouvrier Métallurgiste: no 154, October 1, 1904, p. 4, and no 158 , January 1, 1905, p. 1.

2 Francis Delaisi, "Le Règne de l'Acier", part I, in : Pages Libres, no 245, September 9,1905 , pp. 217-227; part II, ibid., no 246, September 16, 1905, pp. 237-247; part III, ibid., no 247, September 23, 1905, pp. 265-277.

3 Merrheim, "Le Mouvement Ouvrier dans le Bassin de Longwy", cited above, p. 166 , note 1 .

4 XIIIe Congrès National des Ouvriers Métallurgistes, pp. 162-164.

5 Edouard Dolléans, Histoire du Mouvement Ouvrier, Paris, 1957, p. 171; also Edouard Dolléans, Alphonse Merrheim (Paris, 1913), pp. 13-14. Jean Montreuil (Georges Lefranc) has the same information in his Histoire du Mouvement Ouvrier en France, des origines à nos jours (Paris, 1946), p. 300. 
of the steel industry. ${ }^{1}$ More important, however, they demonstrated that all important companies related to the steel industry formed a giant trust (Comite des Forges), which had significant ties with the government. Objectively, revolutionary syndicalists did not match the strength or unity of the trust, a fact which was eventually to convince Merrheim that they would have to work long before they could meet the government and capitalists on more equal terms.

Still, in 1906, neither Merrheim nor the CGT despaired because they had come to believe that they would only achieve meaningful social change and eventual social revolution slowly through patient unionbuilding and frequent confrontations with capitalists. Merrheim, however, participated so thoroughly in trade union activity and studied the organization of capitalism so carefully that he came to emphasize the preparation for revolution much more than the revolution itself. In the process he lost any revolutionary will he may originally have had. Merrheim's caution was significant because he appeared to his colleagues to be an orthodox and anti-reformist revolutionary syndicalist. At all CGT congresses he attended before the First World War, he consistently fought reformism, championed antimilitarism and antipatriotism, and upheld the principle of the general strike. Merrheim maintained his revolutionary rhetoric throughout this period, but his studies encouraged him to work in a reformist manner. Since his research added considerable weight to his position, many in the CGT shared his outlook which only contributed to their similar loss of revolutionary élan. This attitude became significant during and shortly after World War I, when the model of the Russian Revolution and unstable economic and social conditions in France made revolutionary agitation a real possibility. Merrheim and a large number of the CGT refused to exploit revolutionary potential and the opportunity was lost. As for the strike of Hennebont, it was that kind of trade union activity - especially coming so soon after the strikes at Cluses and Longwy that contributed to Merrheim's cautiousness and to his conception of revolutionary syndicalism.

1 See Alphonse Merrheim, L'Organisation Patronale: Syndicats, Comités Régionaux, Ententes et Comptoir, Assurance contre les Grèves (Paris: Imp. La Libératrice, n.d.), 29 pp.; Alphonse Merrheim, "L'Organisation Patronale en France", in: Le Mouvement Socialiste, IIe Série, 10e année, no 200, July 15 , 1908, pp. 5-25; no 201, August 15, 1908, pp. 81-95; no 202, September 15, 1908, pp. 178-197; no 203, October 15, 1908, pp. 270-277; no 204, November 15, 1908 , pp. 339-362; no 205, December 15, 1908, pp. 408-425; no 209, April, 1909, pp. 284-289; no 211, June, 1909, pp. 431-448; nos 215 and 216, November-December, 1908, pp. 321-346. See also C. Gras, "Merrheim et le Capitalisme", in : Le Mouvement Social, no 63 (A pril-June, 1968), pp. 143-163. 